\title{
Antimicrobial Susceptibility Determined by the E Test, Löwenstein-Jensen Proportion, and DNA Sequencing Methods among Mycobacterium tuberculosis Isolates - Discrepancies, Preliminary Results
}

\author{
Maria Inês Moura Freixo*, Paulo CS Caldas**, Abbadi Said***, Fátima Martins**, \\ Rossana Coimbra Brito****, Leila de Souza Fonseca*, Maria Helena Féres Saad/ ${ }^{+}$
}

Laboratório de Hanseníase, Departamento Medicina Tropical, Instituto Oswaldo Cruz-Fiocruz, Av. Brasil 4365, 21045-904

Rio de Janeiro, RJ, Brasil *Instituto de Microbiologia, Universidade Federal do Rio de Janeiro, Rio de Janeiro, RJ Brasil

**Centro de Referência Prof. Hélio Fraga, Ministério da Saúde, Rio de Janeiro, RJ, Brasil ***Suez Canal University School of

Medicine, Ismailia, Egypt $* * * *$ Hospital Pedro Ernesto, Universidade do Estado do Rio de Janeiro, Rio de Janeiro, RJ, Brasil

Mycobacterium tuberculosis strains resistant to streptomycin (SM), isoniazid (INH), and/or rifampin (RIF) as determined by the conventional Löwenstein-Jensen proportion method (LJPM) were compared with the E test, a minimum inhibitory concentration susceptibility method. Discrepant isolates were further evaluated by BACTEC and by DNA sequence analyses for mutations in genes most often associated with resistance to these drugs ( $\operatorname{rps} L$, katG, inhA, and rpoB). Preliminary discordant E test results were seen in $75 \%$ of isolates resistant to SM and in $11 \%$ to INH. Discordance improved for these two drugs (63\%) for SM and none for INH when isolates were re-tested but worsened for RIF (30\%). Despite good agreement between phenotypic results and sequencing analyses, wild type profiles were detected on resistant strains mainly for SM and INH. It should be aware that susceptible isolates according to molecular methods might contain other mechanisms of resistance. Although reproducibility of the LJPM susceptibility method has been established, variable E test results for some M. tuberculosis isolates poses questions regarding its reproducibility particularly the impact of $E$ test performance which may vary among laboratories despite adherence to recommended protocols. Further studies must be done to enlarge the evaluated samples and looked possible mutations outside of the hot spot sequenced gene among discrepant strains.

Key words: Mycobacterium tuberculosis - susceptibility test - DNA sequencing - E test

Advances in health care policies in developed nations offered a goal to eradicate tuberculosis (TB) by the end of the XX century, but it reemerged due primarily to the global human immunodeficiency virus (HIV) epidemic, the large numbers of people trapped in poverty, and due to the disruption of the TB control program. However, $95 \%$ of TB cases occur in developing countries (PablosMéndez et al. 1998) and the disease has remained endemic for many decades.

The treatment of TB requires a multidrug regimen administrated over a long period of time, and a high level of compliance with therapy. The lack of compliance has led to an increase in drug-resistant strains of Mycobacterium tuberculosis (Cohn et al. 1997). For these reasons, rapid identification of mycobacterial isolates, along with rapid susceptibility testing of all isolates of M. tuberculo-

Financial support: subcontract from the J Hopkins University with funds provided by grant 1U19AI45432-01 from NIH (its contents are solely the responsibility of authors and do not necessarily represent the official views of NIH), CNPq (Pronex, Milênio), Faperj, Brazil

${ }^{+}$Corresponding author. Fax: +55-21-2270.9997. E-mail: saad@ioc.fiocruz.br

Received 25 June 2003

Accepted 9 December 2003 sis, has become a critical step for correct therapy selection and for the prevention of the spread of resistant organisms.

In this preliminary study $M$. tuberculosis strains that were resistant to isoniazid (INH), rifampin (RIF) and/or streptomycin (SM) as determined by the LöwensteinJensen proportion method (LJPM) (Canetti et al. 1963), and compared the results an epsilometer test (E test system; AB Biodisk, Solna, Sweden). Strains were further evaluated by a radiometric proportional drug susceptibility assay (BACTEC, Becton-Dickinson, Sparks, MD) and by DNA sequence analysis for mutations in gene regions most often associated with resistance to these drugs in order to evaluate discrepant results as well as correlations with minimum inhibitory concentration (MIC) determined by the E test. The E test was performed as previously described (Wangler \& Mills 1996) with minor modification. Briefly, growth from LJ slants incubated for three weeks at $37^{\circ} \mathrm{C}$ was suspended into a tube containing 3 $\mathrm{mm}$ glass beads and vortexed for $1 \mathrm{~min}$. Following addiction of 5\% PBS-Tween 80, the large particles were left to settle down and the supernatant achieved a turbidity equivalent to that of a McFarland 4 standard. This inoculum was swabbed onto Middlebrook 7H11 agar (Difco, Detroit, MI) plates $(150 \mathrm{~mm})$ supplemented with $0.2 \%$ tyloxapol (Sigma, US) and 10\% OADC (BBL, Cockeysville, MD). After $24 \mathrm{~h}$ incubation at $37^{\circ} \mathrm{C}$ in an atmosphere of $5 \% \mathrm{CO}_{2}$, three $\mathrm{E}$ test strips (kindly provided by $\mathrm{AB}$ 
Biodisk) impregnated with gradients of INH, RIF or SM $(0.016$ to $256 \mu \mathrm{g} / \mathrm{ml})$ were placed on the agar surface plate and incubated as described above. Susceptibility results were interpreted using the following breakpoints: INH, $0.2 \mu \mathrm{g} / \mathrm{ml}$; RIF, > $1 \mathrm{mg} / \mathrm{ml}$; SM, $5 \mu \mathrm{g} / \mathrm{ml}$ (NCCLS 1994). Critical drug concentrations for BACTEC broth testing were $0.1 \mu \mathrm{g} / \mathrm{ml}$ for INH and $2 \mu \mathrm{g} / \mathrm{ml}$ for RIF and SM.

Genotypic analyses were done from crude lysates containing genomic DNA for use as templates for polymerase chain reaction (PCR). Templates for genotypic analyses were crude lysates prepared from Middlebrook 7H9 broth cultures by disruption of cells with siliconized glass beads as previously described (Plikaytis et al. 1990). Regions of rpoB, kat $G$, rpsL, and inhA in which mutations most frequently associated with antituberculosis drug resistance have been found (Ramswamy \& Musser 1998), were amplified by PCR using conditions and oligonucleotide primers that were previously described (Table I). Amplimers were evaluated for mutations using automated DNA sequence analysis performed on an ABI373 sequencing apparatus according to the protocol supplied by the manufacturer using the Big Dye ${ }^{\mathrm{TM}}$ Terminator Cycle Sequencing Ready Reaction Kit (PE Applied Biosystems, Foster City, CA).
It test was performed blindly by different institutions involved in this study. Data analysis was performed using the software EPInfo5.

Patterns of susceptibility to INH, RIF, and SM for 25 M. tuberculosis isolates were determined by the LJPM, at Hélio Fraga National Reference Center of Ministry of Health and Noel Nutels Institute, Rio de Janeiro State Reference Laboratory for TB, Brazil. Single-drug resistance was found among 14 isolates ( 8 to INH, 2 to RIF, and 4 to SM) and 11 were resistant to at least two drugs: 3 were resistant to INH and SM, 7 to INH and RIF and 1 to all three drugs.

The $\mathrm{E}$ test failed to detect SM resistance in 6 of the 8 isolates (75\%); SM resistance was confirmed by BACTEC in 5 of the 6 discrepant isolates (Table II). None showed mutations on rpsL gene regions.

The E test results were discordant for 2 of $19 \mathrm{INH}-$ resistant isolates (strains 12 and 23; Table II). The INH MIC determined by the E test for the two discordant isolates was $0.016 \mu \mathrm{g} / \mathrm{ml}$ and only one (strain 12) was shown to have a kat $G$ mutation. However under $\mathrm{E}$ test re-testing the MICs changed to 4 and $1 \mu \mathrm{g} / \mathrm{ml}$, respectively, and BACTEC confirmed resistant profile. Among the remaining 17 concordant INH ${ }^{\mathrm{R}}$ strains, E test MICs were high for

TABLE I

Genomic regions examined for mutations

\begin{tabular}{lccccccl}
\hline Drug & Gene & Nucleotides & Codons & Primers & $\begin{array}{c}\text { Size of } \\
\text { product }\end{array}$ & $\begin{array}{c}\text { GenBank } \\
\text { Accession nr }\end{array}$ & \multicolumn{1}{c}{ References } \\
\hline RIF & rpob & $2316-2517$ & $481-565$ & BC35/BC41R & $255 \mathrm{bp}$ & 68081 & Abbadi et al. 2001 Miller et al. 1994 \\
INH & katG & $725-1047$ & $243-349$ & BC48/BC51R & $321 \mathrm{bp}$ & U68480 & Abbadi et al. 2001 Telenti et al. 1993 \\
INH & inhA & $56-303$ & $19-101$ & inhA1/inhA2 & $247 \mathrm{bp}$ & U66801 & Telenti et al. 1993 \\
SM & rpsL & $4-310$ & $2-103$ & ML51/ML52R & $306 \mathrm{bp}$ & L25882 & Honoré \& Cole 1994 \\
\hline
\end{tabular}

RIF: rifampim; INH: isoniazid; SM: streptomycin

TABLE II

Discrepant genotypic and/or phenotypic antimicrobial susceptibility results for Mycobacterium tuberculosis isolates

\begin{tabular}{|c|c|c|c|c|c|c|c|c|}
\hline \multirow{2}{*}{$\begin{array}{l}\text { Strain } \\
\text { ID }\end{array}$} & \multirow{2}{*}{$\begin{array}{l}\text { LJPM } \\
\text { patterns }\end{array}$} & \multicolumn{3}{|c|}{ Etest MIC $(\mu \mathrm{g} / \mathrm{ml})$} & \multirow{2}{*}{$\begin{array}{c}\text { BACTEC }^{a} \\
\text { pattern }\end{array}$} & \multicolumn{3}{|c|}{ Relevant genotypic ${ }^{b}$} \\
\hline & & SM & INH & RIF & & $r p s L$ & katG/inhA & $r p o B$ \\
\hline 1 & $\mathrm{SM}^{\mathrm{R}}$ & 4.0 & 0.016 & 0.016 & $\mathrm{SM}^{\mathrm{R}}$ & WT & & \\
\hline 2 & $\mathrm{SM}^{\mathrm{R}}$ & 4.0 & 0.016 & 0.016 & $\mathrm{SM}^{\mathrm{R}}$ & WT & & \\
\hline 3 & $\mathrm{SM}^{\mathrm{R}}$ & 256 & 0.016 & 0.016 & $\mathrm{SM}^{\mathrm{R}}$ & WT & & \\
\hline 4 & $\mathrm{SM}^{\mathrm{R}} / \mathrm{INH}^{\mathrm{R}}$ & 32 & 256.0 & 0.016 & $\mathrm{SM}^{\mathrm{R}} / \mathrm{INH}^{\mathrm{R}}$ & WT & $\mathrm{S}_{315^{\mathrm{T}}}$ & \\
\hline 5 & $\mathrm{SM}^{\mathrm{R}} / \mathrm{INH}^{\mathrm{R}}$ & 1.0 & 256.0 & 0.016 & $\mathrm{SM}^{\mathrm{R}} / \mathrm{INH}^{\mathrm{R}}$ & WT & $\mathrm{S}_{315}^{315^{\mathrm{T}}}$ & \\
\hline 6 & $\mathrm{SM}^{\mathrm{R}} / \mathrm{INH}^{\mathrm{R}} / \mathrm{RIF}^{\mathrm{R}}$ & 1.5 & 4.0 & 256.0 & $\mathrm{SM}^{\mathrm{R}} / \mathrm{INH}^{\mathrm{R}} / \mathrm{RIF}^{\mathrm{R}}$ & WT & $\mathrm{S}_{315^{\mathrm{T}}} \mathrm{T}$ & WT \\
\hline 7 & $\mathrm{SM}^{\mathrm{R}} / \mathrm{INH}^{\mathrm{R}}$ & 1.5 & 0.5 & 0.016 & $\mathrm{SM}^{\mathrm{S}} / \mathrm{INH}^{\mathrm{R}}$ & WT & WT//WT & \\
\hline 8 & $S M^{R}$ & 1.0 & 0.016 & 0.016 & $\mathrm{SM}^{\mathrm{R}}$ & WT & & \\
\hline 11 & $\mathrm{INH}^{\mathrm{R}} / \mathrm{RIF}^{\mathrm{S}} d$ & 0.016 & 32.0 & 256.0 & $\mathrm{RIF}^{\mathrm{S}}$ & & $\mathrm{S}_{315} \mathrm{~T}$ & $\mathrm{H}_{526} \mathrm{D}$ \\
\hline 12 & $\mathrm{INH}^{\mathrm{R}} / \mathrm{RIF}^{\mathrm{R}}$ & 0.016 & $0.016 / 4.0^{c}$ & 256.0 & $\mathrm{INH}^{\mathrm{R}}$ & & $\mathrm{S}_{315}^{315} \mathrm{~T}$ & $\mathrm{H}_{526}^{526} \mathrm{D}$ \\
\hline 13 & $\mathrm{INH}^{\mathrm{R}} / \mathrm{RIF}^{\mathrm{R}}$ & 0.016 & 1.5 & 256.0 & $\mathrm{INH}^{\mathrm{R}} / \mathrm{RIF}^{\mathrm{R}}$ & & WT//WT & $\mathrm{WT}$ \\
\hline 19 & $\mathrm{INH}^{\mathrm{R}}$ & 0.016 & 256.0 & 0.016 & $\mathrm{INH}^{\mathrm{R}}$ & & WT//WT & \\
\hline 21 & $\mathrm{INH}^{\mathrm{R}}$ & 0.016 & 256.0 & 0.016 & ND & & WT/mabA-15 & \\
\hline 23 & INH $^{\mathrm{R}}$ & 0.016 & $0.016 / 1.0^{c}$ & 0.016 & $\mathrm{INH}^{\mathrm{R}}$ & & WT//WT & \\
\hline 24 & $\mathrm{RIF}^{\mathrm{R}} / \mathrm{RIF}^{\mathrm{S} d}$ & 0.016 & 0.016 & $4.0 / 0.016^{d}$ & $\mathrm{RIF}^{\mathrm{S}}$ & & & WT \\
\hline 25 & $\mathrm{RIF}^{\mathrm{R}} / \mathrm{RIF}^{\mathrm{S} d}$ & 0.016 & 0.016 & $2.0 / 0.016^{d}$ & $\mathrm{RIF}^{\mathrm{S}}$ & & & WT \\
\hline
\end{tabular}

LJPM: Lowenstein-Jensen proportion method; $a$ : BACTEC testing was performed only for isolates showing discrepancies by other methods; $b$ : gene regions (Table I) were sequenced using ABI automatic DNA sequencer; $c$ : susceptible initially but resistant after retestimg; $d$ : resistante initially but susceptible under re-testing. Drug concentrations breaking point for E test were: SM (streptomycin) $2 \mu \mathrm{g} / \mathrm{ml}$; RIF (rifampin) < 1; INH (isoniazid) $0.2 \mu \mathrm{g} / \mathrm{ml}$; ND: not done; WT: wildtype 
8 isolates ( $\mathrm{MIC}=256 \mu \mathrm{g} / \mathrm{ml}$ ). For all except one isolate, three distinct single nucleotide polymorphisms (SNPs) in $k a t G$ gene were observed in 14 isolates; 12 harbored the most commonly found substitution (Ramswamy \& Musser 1998), Ser $_{315} \mathrm{Thr}$, and one each had a rare mutation $\left(\operatorname{Ser}_{315} \mathrm{Arg}\right)$ or a previously unreported substitution $\left(\mathrm{Gln}_{273} \mathrm{Ser}\right)$. MICs for these two, respectively, were $32 \mu \mathrm{g} /$ $\mathrm{ml}$ and $256 \mu \mathrm{g} / \mathrm{ml}$ ). In five isolates found $\mathrm{INH}^{\mathrm{R}}$ by LJPM/ BACTEC no mutation in the katG gene region examined was detected (26\%), and three of them yielded low levels of resistance (strains 7, 13, 23) and two had high MICs (strains 19, 21, Table II). All INH-resistant isolates were examined for mutations in a 248-bp region of the inhA structural gene and one (strain 21) had a mabA-15 mutation. Most isolates that were WT in kat $G$ and inhA showed resistance at low INH MICs $(\leq 1.5 \mu \mathrm{g} / \mathrm{ml})$ and resistance were confirmed by BACTEC testing.

Concordance between the E test and LJPM results was found initially for nine RIF-resistant isolates, seven of which were highly resistant $(\mathrm{MIC}=256 \mu \mathrm{g} / \mathrm{ml}$ ). Mutations in $r p o B$ were found in five isolates: His ${ }_{526} \mathrm{Asp}$, His $_{526}$ Val, His ${ }_{526}$ Tyr, Asp ${ }_{516}$ Val, and Ser $_{531}$ Leu. Four $\mathrm{RIF}^{\mathrm{K}}$ isolates had no rpoB mutations: two each had high $(256 \mu \mathrm{g} / \mathrm{ml}$, strains 6,13$)$ and low (4 and $2 \mu \mathrm{g} / \mathrm{ml}$, strains 24, 25) RIF MICs. These latter isolates (Table II), were retested and found susceptible by all tests. High RIF MICs found for the isolates 6 and 13 had resistant profile confirmed by all phenotypic methods. One discrepant isolate (11) was initially found to be RIF-resistant by LJPM and E test $(\mathrm{MIC}=256 \mu \mathrm{g} / \mathrm{ml})$, however by BACTEC it was susceptible. Although RIF ${ }^{\mathrm{S}}$ was confirmed by BACTEC, an rpoB mutation ( $\mathrm{His}_{526} \mathrm{Asp}$ ) was also found. Under retest LJPM give susceptible profile. One possible explanation for the discrepancies seen among strains 11, 24, and 25 may be related with hetero-resistant clones, e. g., those present in a single colony, however we could not prove this hypothesis, isolating both type of colonies, because of the samples' death.

It is well known that spontaneous resistance to isoniazid occurs once every $10^{6}$ microorganisms and for RIF larger organism population is need (once every $10^{8}$ ). In general, multidrug resistance is acquired in two steps, with initial INH resistance development rather than RIF resistance. In our finding $100 \%$ of RIF resistant strains were also INH resistant, this may confirm that RIF is a good marker to identify MDR M. tuberculosis (Hazbón et al. 2000).

Our data demonstrated good overall agreement between LJPM and E test methods for INH and RIF as reported previously (Wangler \& Mills 1996, Hazbón et al. 2000), but more discrepancies were found for SM. The extent of concordance was improved for some isolates only after re-testing. This may be related to the inoculum preparation what led a poor growth in the initial testing. Except for two M. tuberculosis isolates, SM MICs determined by the E test were low $(<4 \mu \mathrm{g} / \mathrm{ml})$. However, if the endpoint interpretation for SM were lowered to $4 \mu \mathrm{g} / \mathrm{ml}$ as used for LJPM interpretation rather than $5 \mu \mathrm{g} / \mathrm{ml}$ our results would have been more concordant. No rpsL mutations were found (Table II) but this finding may not be surprising since mutations in this gene are typically asso- ciated with much higher MICs, (e.g. $\geq 500 \mu \mathrm{g} / \mathrm{ml})$ and MICs among our isolates were $\leq 256 \mu \mathrm{g} / \mathrm{ml}$ (Cooksey et al. 1996, Meier et al. 1996). An additional cause for discordance, particularly when re-testing was performed, may be due to selection of drug-resistant mutants from subcultures.

Our findings suggest that the E test may be useful for rapid screening in some sets of strains, as isolates from patients under epidemiologic investigation or those with suspicion of infection with INH- and/or RIF-resistant strains (Dobner et al. 1997, Hazbón et al. 2000). Nucleic acid-based assays for the detection of resistance are typically easy and rapid and may offer advantages over phenotypic tests for quick identification of MDR isolates, perhaps even for culture-negative specimens. However, as reported previously (Cooksey et al. 1997, Ramswamy \& Masser 1998, Spindola de Miranda et al. 2001) and confirmed in this study, some resistant isolates may not be detected through genetic alteration of the target gene segment. In this study most of the WT profile was seen among low MIC resistant strains, however among mutated resistant strains significant correlation was detected in those with high MICs $(\mathrm{p}=0.06)$.

In our preliminary study discrepancies related to molecular resistance detection were significantly higher than among phenotypic assays $(14 / 25$ x 6/25, p =0.04). Mutations in these strains most likely were located outside of the target segment gene or other mechanisms of resistance may have been responsible (Meier et al. 1996, Ramswamy \& Masser 1998, Spindola de Miranda et al. 2001) as already observed for INH $^{\mathrm{R}}$ strains. Nonetheless good agreement was found between E test and LJPM as reported previously (Wangler \& Mills 1996), for INH and amino acid substitutions located at codon position 315 in $k a t G$ was the most frequently associated genotype (Cooksey et al. 1997, Dobner et al. 1997). Overall, the routine use of molecular techniques for the analysis of resistance is dependent on the prevalence of the resistancecausing mutation. The use of molecular techniques seems to provide incomplete coverage and may vary between different areas (Spindola de Miranda et al. 2001, Bártfai et al 2001). As rapid detection methods that inherently may overcome problems related to the slow growth of $M$. $t u$ berculosis, they are potentially very helpful for controlling the spread of resistant strains especially MDR strains. Until further improvements in molecular technologies for this purpose are achieved, however, confirmation of genotypic drug susceptibility results must continue to be confirmed by the most appropriate conventional phenotypic susceptibility method. Further studies must be done to enlarge the evaluated samples and looked possible mutations outside of the hot spot sequenced gene among discrepant strains.

\section{ACKNOWLEDGMENTS}

To Dr Robert Cooksey from Tuberculosis Laboratory, CDC, Atlanta, US, for his helpful advises and comments.

\section{REFERENCES}

Abbadi S, Rasheed HG, Morlock GP, Woodley CL, El Shanawy O, Cooksey RC 2001. Characterization of IS6110 restriction fragment length polymorphisms patterns and mecha- 
nisms of antimicrobial resistance for multitidrug-resistant isolates of Mycobacterium tuberculosis from a major reference hospital in Assiut, Egypt. J Clin Microbiol 39: 23302334.

Bártfai Z, Somoskövi A, Ködmön C, Zabó N, Puskás E, Kosztolányi L, Faragó E, Mester J, Parsons LM, Salfinger M 2001. Molecular characterization of rifampicin-resistant isolates of Mycobacterium tuberculosis from Hungary by DNA sequencing and line probe assay. J Clin Microbiol 39: 3736-3739.

Canetti G, Rist N, Grosset J 1963. Mesure de la sensibilité du baculle tuberculeux aux drogues antibacullaires par la méthode des proportions. Methodologie, critères de résistance, résultats, interprétation. Rev Tuberculose Pneumol 27: 217-272.

Cohn DL, Bustreo F, Raviglione MC 1997. Drug-resistant tuberculosis: review of the worldwide situation and the $\mathrm{WHO} /$ IUATLD global surveillance project. Clin Infect Dis 24: S121-130.

Cooksey RC, Morlock GP, Glickman S, Crawford JT 1997. Evaluation of a line probe assay kit for characterization of rpoB mutations in rifampin-resistant Mycobacterium tuberculosis isolates from New York City. J Clin Microbiol 35: 1281-1283.

Cooksey RC, Morlock GP, McQueen A, Glickman SE, Crawford JT 1996. Characterization of streptomycin resistance mechanisms among Mycobacterium tuberculosis isolates from patients in New York City. Antimicrob Agents Chemother 40: 1186-1188.

Dobner P, Rusch-Gerdes S, Bretzel G, Feldmann K, Rifai M, Loscher T, Rinder 1997. Usefulness of Mycobacterium tuberculosis genomic mutations in the genes kat $G$ and inhA for the prediction of isoniazid resistance. Int J Tuberc Lung Dis 1: 365-369.

Hazbón MH, Orozco M del S, Labrada LA, Tovar R, Weigle KA, Wangler A 2000. Evaluation for susceptibility testing of multidrug resistant isolates of Mycobacterium tuberculo- sis. J Clin Microbiol 38: 4599-4603.

Honore N, Cole ST 1994. Streptomycin resistance in mycobacteria. Antimicrob Agents Chemother 38: 328-242.

Meier A, Sander P, Schaper KJ, Scholz M, Böttger EC 1996. Correlation of molecular resistance mechanisms and phenotypic resistance levels in streptomycin-resistant Mycobacterium tuberculosis. Antimicrob Agents Chemother 40: 24522454.

Miller LP, Crawford JT, Shinnick TM 1994. The rpoB gene of Mycobacterium tuberculosis. Antimicrob Agents Chemother 38: 805-811.

NCCLS-National Committee for Clinical Laboratory Standards 1994. Antimycobacterial. susceptibility testing for Mycobacterium tuberculosis. Tentative standard M24-T, Villa Nova, PA.

Pablos-Méndez, A., Raviglione MC, Laszlo A, Binkin N, Rieder HL, Bustreo F, Cohn DL, Lambregts-van Weezenbeek CSB, Kim SJ, Chaulet P, Nunn P 1998. Global surveillance for anti-tuberculosis drug resistance, 1994-1997. N Engl J Med 338: 1641-1649.

Plikaytis BB, Gelber RH, Shinnick TM 1990. Rapid and sensitive detection of Mycobacterium leprae using a nestedprimer gene amplification assay. J Clin Microbiol 28: 19131917.

Ramswamy S, Musser JM 1998. Molecular genetic basis of antimicrobial agent resistance in Mycobacterium tuberculosis: 1998 update. Tubercle and Lung Dis 79: 3-29.

Spindola de Miranda S, Kritski A, Filliol I, Mabilat C, Panteix G, Drouet E 2001. Mutations in rpoB gene of rifampicinresistant Mycobacterium tuberculosis strains isolated in Brazil and France. Mem Inst Oswaldo Cruz 96: 247-250.

Telenti A, Imboden P, Marchesi F, Lowrie D, Cole S, Colston MJ, Matter L, Schopfer K, Bodmer T 1993. Detection of rifampicin-resistance mutations in Mycobacterium tuberculosis. Lancet 341: 647-650.

Wangler A, Mills K 1996. Testing Mycobacterium tuberculosis susceptibility to ethambutol, isoniazid, rifampin, and streptomycin by using E test. J Clin Microbiol 364: 1672-1676. 